\title{
Potential of catch crops to reduce nitrogen leaching in New Zealand winter grazing systems
}

\author{
B.J. MALCOLM ${ }^{1}$, P.L. CAREY ${ }^{2}$, E.I. TEIXEIRA ${ }^{1}$, P.R. JOHNSTONE ${ }^{1}$, S.C. MALEY ${ }^{1}$ and J.M. DE RUITER ${ }^{1}$ \\ ${ }^{1}$ The New Zealand Institute for Plant \& Food Research Limited, Lincoln, New Zealand \\ ${ }^{2}$ Lincoln Agritech Limited, Lincoln, New Zealand \\ Brendon.Malcolm@plantandfood.co.nz
}

\begin{abstract}
Winter grazing of fodder beet and kale is common practice in many regions of New Zealand. However, large quantities of urine-nitrogen $(\mathrm{N})$ is returned by livestock onto bare soil during grazing at a period when the risk of drainage is high. Results from recent field trials in the Canterbury region show that sowing a catch crop directly after winter forage grazing can reduce $\mathrm{N}$ leaching losses by up to $49 \%$ compared with fallow soil, as well as offer significant gains in feed production, via additional annual production from the catch crop. However, the magnitude of effectiveness varies in response to crop management, catch crop genotype, soil type and seasonal weather conditions. For example, early-sown cereal genotypes adapted to lower temperatures provide the greatest potential to reduce leaching. This summary also highlights three important areas for future research: (i) overcoming the practical challenges of establishing catch crops in unfavourable conditions, (ii) development of biophysical models that can predict outcomes over a wide range of production systems and conditions, and (iii) quantification of other processes in the $\mathrm{N}$ cycle causing changes in $\mathrm{N}$ leaching, e.g. microbial immobilisation of $\mathrm{N}$.
\end{abstract}

Keywords: Avena sativa, forage crop, nitrate leaching, kale, fodder beet

\section{Introduction}

Winter grazing of forage crops such as kale (Brassica oleracea var. acephala) and fodder beet (Beta vulgaris spp. vulgaris) is common practice in New Zealand, particularly in the South Island. These systems typically result in fallow soils for 3-5 months until a new crop is established in spring (Edwards et al. 2014). The risk of nitrogen $(\mathrm{N})$ leaching from large numbers of urine patches deposited during grazing is greatest during these winter and early-spring fallow periods with estimated losses between 50 and 180 $\mathrm{kg} \mathrm{N} / \mathrm{ha}$ (Shepherd et al. 2012; Smith et al. 2012; Monaghan et al. 2013; Malcolm et al. 2016a). There is a high probability of soil drainage and nutrient loss in these grazing systems because precipitation normally exceeds evapotranspiration in winter and early-spring. Recent research has demonstrated that catch crops (e.g. oats), sown in winter after forage grazing, can be successfully used to reduce drainage and take up $\mathrm{N}$ from the soil, ultimately reducing $\mathrm{N}$ leaching losses (Carey et al. 2016; Malcolm et al. 2016b). Catch crops, also commonly referred to as cover crops, are not new practises and have been extensively used in cropping systems (primarily sown in autumn), to conserve nutrients over the winter and provide ground cover for weed control and soil stabilisation (Francis et al. 1995; Fraser et al. 2013). The novelty around recent studies, however, relates to establishing catch crops after forage crop grazing for better environmental outcomes during the coolest months of the year.

The objective of this paper is to summarise recent research (including recent unpublished data), on the potential benefits and challenges of using catch crops to mitigate $\mathrm{N}$ leaching losses in winter-grazed forage crop systems of New Zealand. The following sections highlight key findings related to $\mathrm{N}$ losses (environmental dimension) and attainable yields (production dimension) of these agricultural systems and identify key knowledge gaps and areas for future research. Although the majority of research considered in this paper was performed in the South Island (particularly Canterbury), the principles also apply to other regions of New Zealand.

\section{Effect of catch crops on $\mathrm{N}$ leaching}

Catch crops sown after winter forage crop grazing have been shown to significantly reduce the amount of soil $\mathrm{N}$ at risk of leaching (Malcolm et al. 2016b). Recent field datasets from the Forages for Reduced Nitrate Leaching (FRNL) programme have indicated that oats, sown in either July or August, substantially reduced the amount of mineral $\mathrm{N}$ remaining in the soil profile in late November by up to $86 \%$, compared with that in fallow plots (Malcolm et al. 2016b). A key characteristic of this system is that more substantial reductions in soil $\mathrm{N}$ occur in the mid to late part of the catch crop growth cycle, from mid-September onwards under Canterbury conditions, when a flush of canopy expansion creates demand for $\mathrm{N}$ uptake by the crop (Malcolm et al. 2016b; B.J. Malcolm, unpublished data). This implies that the risk of $\mathrm{N}$ losses is more likely to be reduced during years when drainage events occur in late-winter and spring, particularly if 


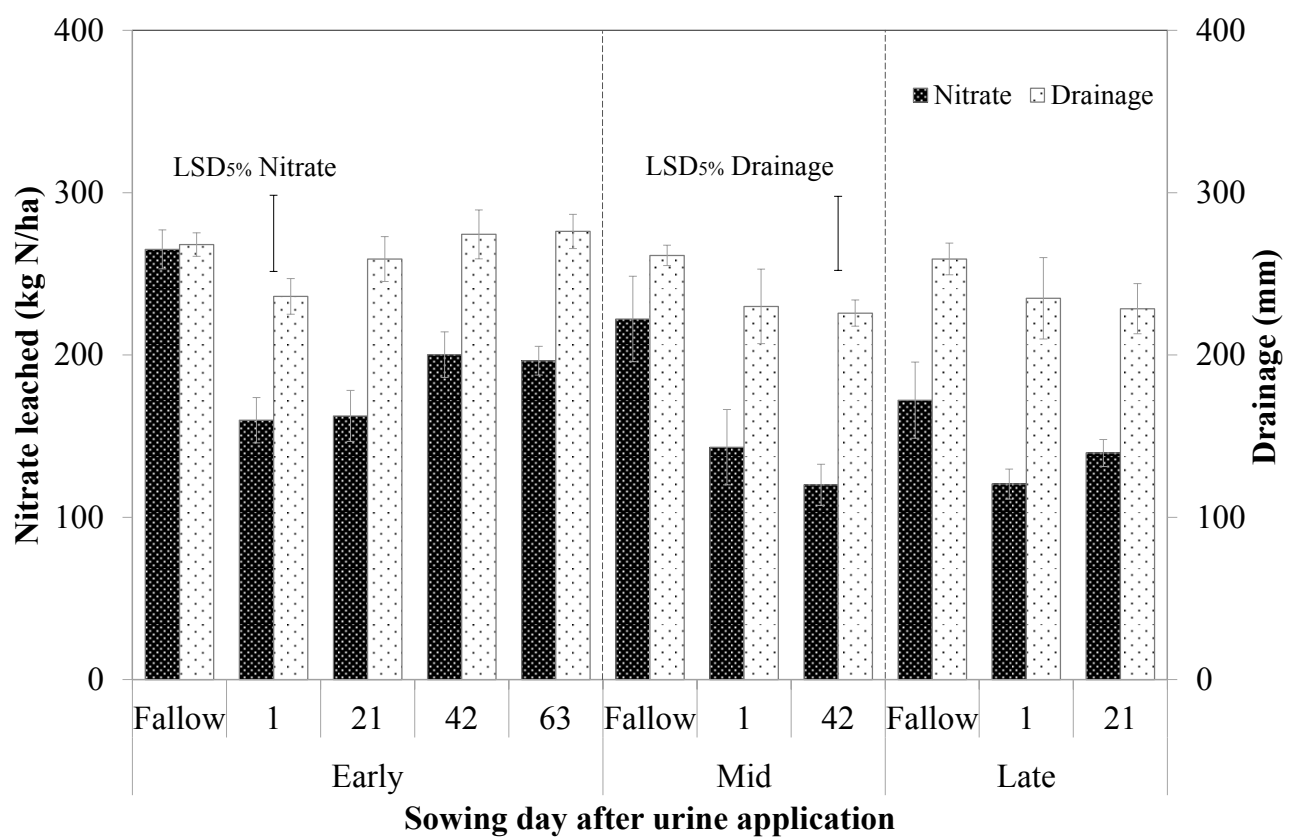

Figure $1 \quad$ Nitrate and drainage losses for 'Early' (June 5th), 'Mid' (July 5th) and 'Late' (July 25th) urine applications (350 kg N/ha) after simulated winter forage grazing with oats sown after 1,21, 42 and 63 days post-urine application (adapted from Carey et al. 2016).

previous weather and soil conditions (during the initial slow stage of crop growth) enable $\mathrm{N}$ loads to remain within reach of the established root system.

The effect of catch crops on actual $\mathrm{N}$ leaching losses has been tested using field monolith lysimeters consisting of stony Balmoral silt loam soil, and results showed a $19-49 \% \mathrm{~N}$ loss reduction by catch crop oats (sown between 1 and 63 days after urine deposition in June and July) compared with fallow treatments (Figure 1), in a relatively dry winter-spring (approx. $180 \mathrm{~mm}$ of rain fell between 1st June to 1st November 2014; irrigation water was applied during November and December to bridge the rainfall deficit and achieve a normal amount of drainage water; approx. $260 \mathrm{~mm}$ ) (Carey et al. 2016). This work also demonstrated that the earlier the crop is established after grazing, the greater the potential to reduce $\mathrm{N}$ leaching, primarily due to a longer growth period that enabled earlier canopy expansion. Another recent FRNL field monolith lysimeter experiment on a Balmoral soil, during a particularly wet winter, showed a similar degree of $\mathrm{N}$ loss reduction (up to $44 \%$ in relation to fallow by late spring) when oats were sown directly after urine application in early-July or early-August (Figure 2; B.J. Malcolm, unpublished data).

An important consideration is the choice of catch crop genotype. For example, Carey et al. (2017) showed that over the critical winter-spring drainage period, oats reduced nitrate leaching by $25 \%$ compared with Italian ryegrass due to earlier establishment. More recent research in the FRNL programme indicates that a wide range of cereal species (ryecorn, triticale, wheat and barley) are comparable to oats in terms of growth, $\mathrm{N}$ uptake and effect on soil $\mathrm{N}$ and can fulfil the role of an effective catch crop (B.J. Malcolm, unpublished data). This provides greater flexibility to the farmer to select catch crops that best fit within the rotation system.

\section{Key processes for reducing $\mathbf{N}$ leaching losses}

The effectiveness of catch crops to reduce $\mathrm{N}$ leaching losses from winter-grazed forage crops is driven by two main processes: i) $\mathrm{N}$ uptake by the crop, and ii) reduced drainage.

\section{Nitrogen uptake by the crop}

Several studies have indicated that the timing and amount of $\mathrm{N}$ uptake by the crop is an important driver behind the success of catch crops. In the lysimeter studies of Carey et al. (2016), between 60 and $80 \mathrm{~kg} \mathrm{~N} / \mathrm{ha}$ was taken up in aboveground crop biomass during the winter/spring. In large field plot trials, $178-270 \mathrm{~kg} \mathrm{~N} /$ ha was captured aboveground by oats in simulated urine patch areas by green-chop silage maturity in November (Malcolm et al. 2016b; B.J. Malcolm, unpublished data). The lesser amounts of $\mathrm{N}$ captured in the lysimeter experiment was likely due to the restrictive nature of lysimeters in terms of root system development. Importantly, $\mathrm{N}$ taken up by the crop during the main leaching period (approx. June 


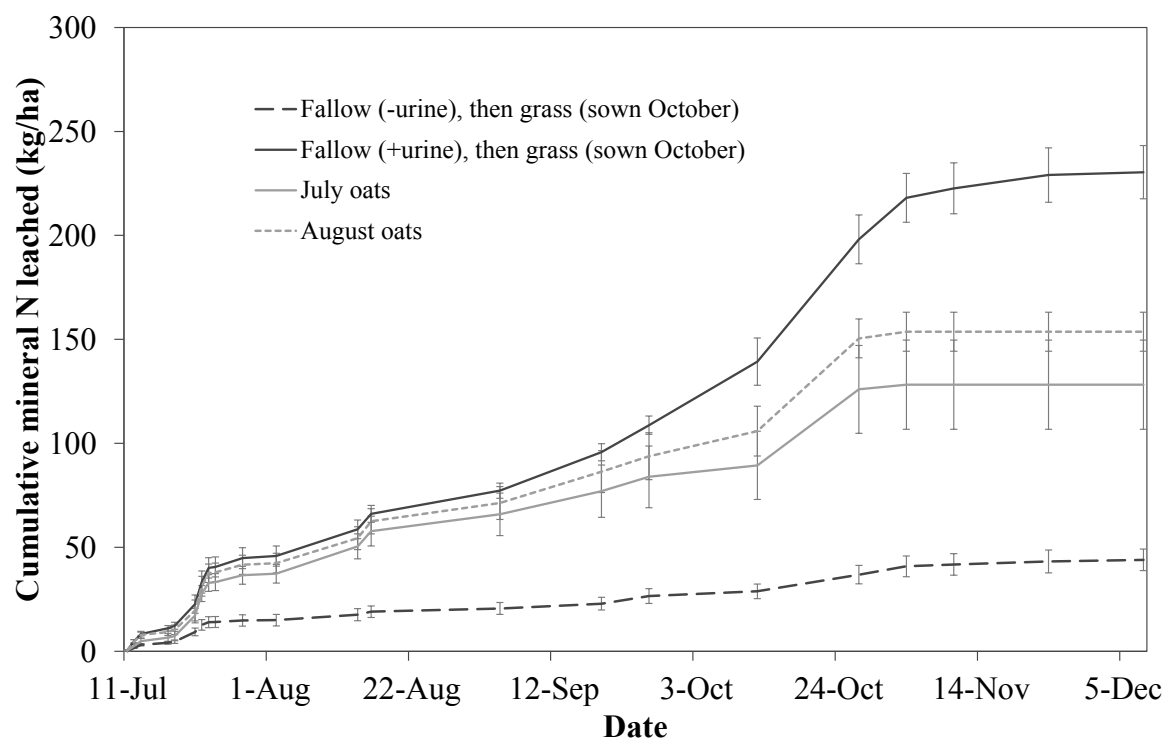

Figure 2 Cumulative mineral nitrogen $(\mathrm{N})$ (ammonium + nitrate) leaching losses from stony Balmoral field monolith lysimeters, following artificial urine deposition ( $300 \mathrm{~kg} \mathrm{~N} / \mathrm{ha}$ ) in early-July 2017, after sowing of catch crop oats in early-July or earlyAugust. The trial was conducted at the Lincoln University Research Dairy Farm, Lincoln, New Zealand (B.J. Malcolm, unpublished data).

to October) is most critical as it reduces the risk of $\mathrm{N}$ leaching during subsequent drainage events. The FRNL large plot trials indicate that approximately $35-65 \mathrm{~kg}$ $\mathrm{N} /$ ha is captured in aboveground crop biomass by midSeptember/early-October following a late- June/earlyJuly sowing (Malcolm et al. 2016b; B.J. Malcolm, unpublished data).

The timing of sowing, as well as weather conditions, can have a substantial effect on growth and when $\mathrm{N}$ is taken up by the crop (Yusoff et al. 2012; Teixeira et al. 2016; Zyskowski et al. 2016). An FRNL trial in 2017 where oats were sown marginally earlier (mid-June) indicated that $208 \mathrm{~kg} \mathrm{~N} / \mathrm{ha}$ was taken up aboveground by the crop by 11 October in a simulated urine patch (B.J. Malcolm, unpublished data). This is similar to the amounts of $\mathrm{N}$ accounted for in the aboveground biomass of winter cover crops of forage oats or forage rape (200-300 kg N/ha) sown in autumn as part of an arable crop rotation (Fraser et al. 2013).

Root systems also have the ability to remove and store N. However, there is evidence from recent work in FRNL that shows the total amount of $\mathrm{N}$ in root systems is low compared with that in the aboveground biomass, and therefore its impact on the $\mathrm{N}$ balance is likely to be small. Results from the 2017 FRNL field plot trial indicated that $<10 \mathrm{~kg} \mathrm{~N} /$ ha was contained in root systems of oats between establishment and early November compared to up to $270 \mathrm{~kg} \mathrm{~N} / \mathrm{ha}$ in the aboveground biomass (Table 1) (B.J. Malcolm, unpublished data). Additionally, this work (which included a variety of cereal species) suggested that faster growing root systems do not necessarily result in reduced $\mathrm{N}$ leaching risk, supporting findings of Malcolm et al. (2015) in a study of Italian ryegrass and tall fescue-based pastures that showed winter activity/root metabolic activity was more important than specific root architecture (e.g. deep roots) in terms of $\mathrm{N}$ recovery and reduced $\mathrm{N}$ leaching.

\section{Reduced drainage}

Research has shown that the ability of catch crops to reduce drainage volume is potentially just as

Table 1 Nitrogen $(\mathrm{N})$ content and amount of $\mathrm{N}$ captured by roots (recovered from $0-90 \mathrm{~cm}$ soil depth in late-October) of different cereal species sown in late-June 2017 in field plots simulating urine $\mathrm{N}$ deposition (400 kg N/ha applied as urea on the day of sowing). The trial was carried out at Plant \& Food Research, Lincoln, New Zealand (B.J. Malcolm, unpublished data).

\begin{tabular}{lcc}
\hline Species & $\begin{array}{c}\text { Root N content } \\
(\%)\end{array}$ & $\begin{array}{c}\text { Amount of root N captured } \\
\text { (kg/ha) }\end{array}$ \\
\hline Oats & 0.96 & 6.74 \\
Ryecorn & 1.10 & 5.19 \\
Triticale & 1.05 & 5.54 \\
Wheat & 1.13 & 6.79 \\
Barley & 1.25 & 9.51 \\
\hline P value & - & 0.066 \\
LSD $_{5 \%}$ & - & 3.05 \\
\hline
\end{tabular}


important as $\mathrm{N}$ uptake. This is driven by higher rates of evapotranspiration compared with fallow soil given the presence of an actively growing crop which is transpiring. In the study of Carey et al. (2016), catch crops reduced the amount of drainage water by approximately $13 \%$ compared to fallow soil. Carey et al. (2017) also concluded that the lower leaching losses beneath oats compared with Italian ryegrass was due to the reduction in drainage volume. Preliminary data from the 2017 FRNL lysimeter experiment showed that drainage volume under July or August sown oats was reduced by $22-30 \%$ compared to a conventional fallow treatment (B.J. Malcolm, unpublished data).

Importantly, in dryland systems where subsequent spring crops might heavily rely on stored water from winter rains, catch crops should be implemented more carefully because they can deplete soil water required for mid and late-season growth (Carey et al. 2017).

As a consequence of reduced drainage, and/or a dry winter in general, it is possible that $\mathrm{N}$ not taken up by the crop remains within various layers of the soil profile at the end of the initial leaching period, which may or may not be picked up by the subsequent spring crop. Shepherd et al. (2017) showed that a significant proportion of winter-deposited urine $\mathrm{N}$ can be leached during the second winter. Similarly, in an arable rotation Fraser et al. (2013) showed a large spike in N leached during the year that followed a particularly dry winter. Therefore, future studies should also consider the potential effects of catch crops over longer crop rotations, by accounting for losses over a second winter.

\section{Other potential processes involved}

An interesting observation from the various FRNL trials is that often the reductions in soil $\mathrm{N}$ under catch crops, compared to fallow soil, is greater than the amount of $\mathrm{N}$ accounted for in the aboveground biomass or total biomass (i.e. accounting for the $\mathrm{N}$ in the root systems). One possible explanation for this is $\mathrm{N}$ immobilisation, possibly driven by sequestration of carbon (C) from root exudates and/or root turnover. Some studies have shown that approximately 1-3 t C/ ha can be added to soils through pasture and cereal crop root systems via root turnover and exudation during the vegetation period (Kuzyakov \& Domanski 2000; Rees et al. 2005; McNally 2016). Comparatively little is known about the amount and types of $\mathrm{C}$ added to soil under newly established catch crops and the possible effects on microbial $\mathrm{N}$ immobilisation. This is an area that requires investigation.

Soil temperature may also play a part in determining nitrate leaching losses. Recent research by Carey et al. (2018) has shown that lower soil temperatures under simulated winter forage grazing decreases the rate of nitrification, and thus nitrate leaching losses, at least in the first few months after urine application when soil temperatures remain low $\left(<5^{\circ} \mathrm{C}\right)$. Once soil temperatures increase to $\sim 10^{\circ} \mathrm{C}$, nitrification is relatively rapid in response to the surge in ammoniaoxidising bacteria (AOB; primarily responsible for the conversion of ammonium into nitrate, i.e. nitrification) abundance and thus, the potential for large nitrate leaching losses increases accordingly. It is at this point that cereals such as oats also experience a rapid rate of development. Thus, early establishment is critical to decreasing the risk of nitrate leaching losses. The difficulty of establishing oats early in wetter, colder regions such as Southland may be offset by a potentially longer window of opportunity to establish the crop before nitrification is complete. Whether this window actually exists remains an area of interest.

\section{Effect of catch crops on productivity}

Establishing a cereal catch crop after winter grazing can offer additional per hectare annual biomass production, and in turn, higher farm productivity. For example, an oat crop grown in sequence with kale in Canterbury can yield as much as $7 \mathrm{t} \mathrm{DM} / \mathrm{ha} /$ year more feed than a kaleonly system, at a similar cost of production (Edwards et al. 2014; DairyNZ 2015). Similarly, Malcolm et al. (2017) showed that oats sown in July after winter-grazed fodder beet or kale could produce yields of between 7 and $10 \mathrm{t} \mathrm{DM} /$ ha by 24 November at relatively low cost $(<\$ 0.11 / \mathrm{kg} \mathrm{DM})$.

On deeper soils, the production potential of oats might be higher than those grown on stony soils, because of higher soil water and nutrient-holding capacities. Yields of 6-12 t DM/ha in large field plots simulating urine and non-urine patch areas have been reported on Templeton silt loam soil when grown through until green-chop silage maturity (Malcolm et al. 2016b). Importantly, the research shows that most of the biomass accumulates during October and November (example given in Figure 3a), which coincides with when crops have reached near full canopy closure (Figure $3 b$ ).

Timing of harvest can have important implications with regards to productivity and crop quality, especially metabolisable energy (ME). Generally, the ideal time to harvest is at green-chop silage maturity [growth stage (GS) 43-GS 59; Zadoks et al. 1974], which represents the point at which biomass production, $\mathrm{N}$ uptake and crop quality components are balanced. Delaying harvest time beyond the green-chop silage maturity stage results in an initial decline in ME on a $/ \mathrm{kg}$ of DM basis, and then an increase as starch is stored during grain filling. After the green-chop silage maturity stage, stem growth and fibre production causes a temporary reduction in the overall feed value. Optimum wholecrop silage quality coincides with the end of grain filling (GS 87); however, the best time for whole-crop 
silage harvest is determined by the whole crop moisture content within the range of $35-42 \%$ DM (de Ruiter et al. 2002), which may occur before the completion of grain fill. In terms of crude protein content, a steady decline occurs during the weeks leading up to green-chop silage maturity (Malcolm et al. 2017).

\section{A role for biophysical models in catch crop assessments}

An inherent characteristic of winter grazing systems with catch crops is the sensitivity of $\mathrm{N}$ leaching losses to inter-annual weather variability and management interactions (Teixeira et al. 2016). The amount and timing of rainfall largely influences the effectiveness of catch crops to mitigate $\mathrm{N}$ leaching (Teixeira et al. 2016; Zyskowski et al. 2016). For example, intense rainfall events resulting in drainage before catch crop establishment are likely to compromise the effectiveness of catch crops to reduce $\mathrm{N}$ leaching losses. Similarly, prevailing temperatures influence how fast $\mathrm{N}$ is mineralised and catch crop canopies expand. All these crop and soil processes occur simultaneously and cannot be easily replicated in different field experiments. However, once the individual biophysical processes that influence $\mathrm{N}$ dynamics are understood and quantified (e.g. $\mathrm{N}$ mineralisation and canopy expansion) these can be represented in biophysical models. These models can then assess the net result ( $\mathrm{N}$ losses and crop yield) across multiple years considering different growth conditions. Such a measure of variability is essential to offer insights into the probabilistic aspect of catch crop response in a given climate-soil-managementgenotype combination. In addition, biophysical models such as APSIM (Holzworth et al. 2014) enable the
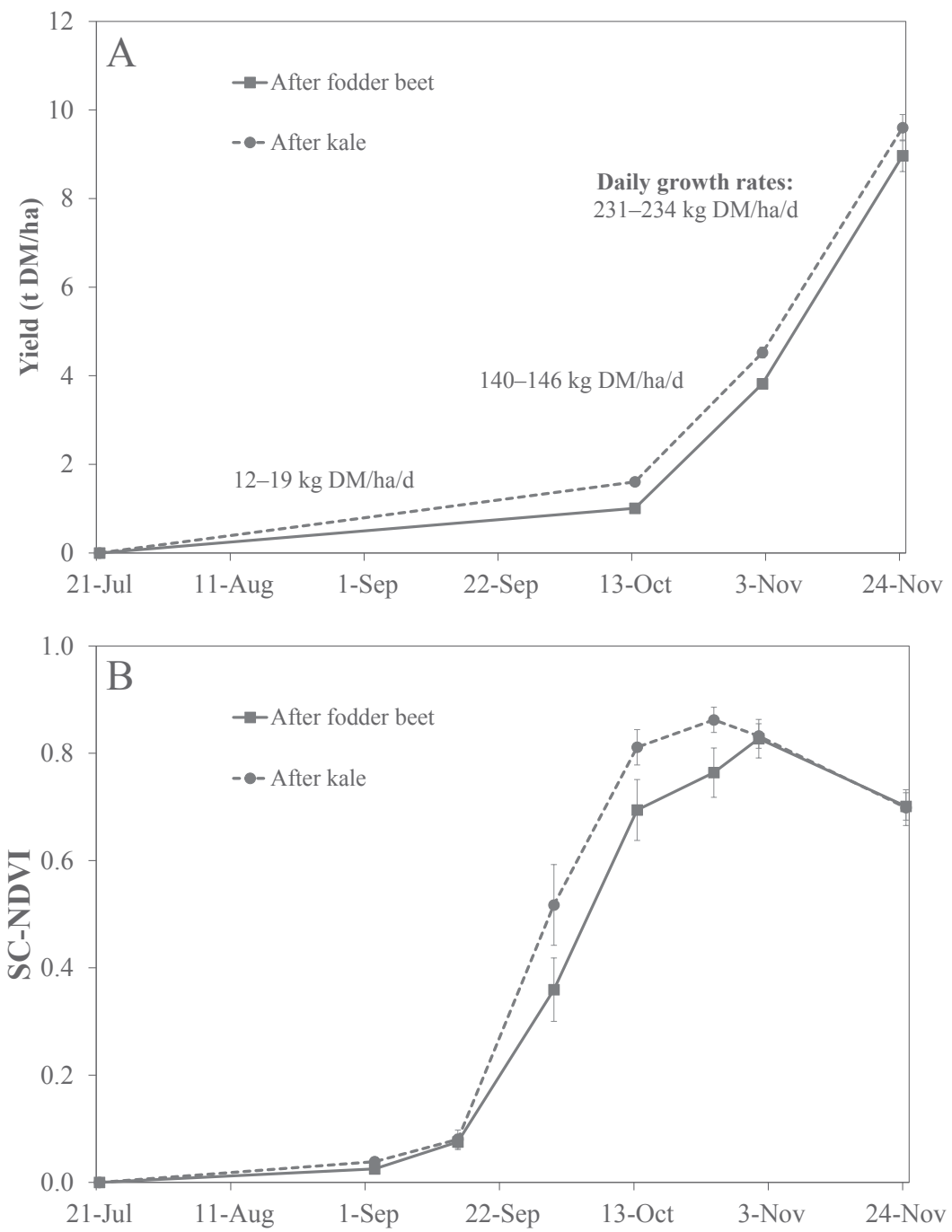

Figure 3 Yield (t DM/ha) (A) and proportional rate of development (scaled normalised difference vegetation index, SC-NDVI) (B) of oat catch crops sown in mid-July 2016 after winter grazed fodder beet and kale on Balmoral/Lismore stony silt loam at Lincoln University's Ashley Dene Research and Development Station (adapted from Malcolm et al. 2017).

representation of different genotype characteristics (e.g. root depth and sensitivity to low temperatures) which allow for identifying plant traits that better contribute to the catch crop effectiveness. Such response patterns, found through a combination of experimentation and biophysical modelling, can also be included in nutrient budget decision tools such as OVERSEER ${ }^{\circledR}$, and targeted in future breeding initiatives.

\section{Practical implications}

There are obvious practical challenges with sowing of catch crops in the middle of winter, particularly in wet and cold conditions. Research in small plot situations 
has shown that cereal catch crops can be successfully established under harsh winter environments, but in some years, particularly on fine-textured soils, it is unlikely that sowing will be possible until late-winter/ spring. In situations such as this, there is opportunity to investigate novel techniques of getting seed into the ground that result in successful crop establishment. On heavy poorly-drained soils where $\mathrm{N}$ leaching losses are not as prevalent, delaying sowing until spring may not actually compromise potential environmental gains. As indicated above, biophysical models can help to answer these types of questions around timing of sowing for any given season/rainfall pattern, to help determine under which circumstances catch crops are likely to provide an environmental and/or production benefit, or not.

In a dry winter (i.e. approx. $55 \mathrm{~mm}$ rainfall during July and August), trials have shown that a comparison of pre-drilling cultivation and direct-drilling after grazed kale can result in equally successful stands of oat catch crops (Malcolm et al. 2017). After fodder beet, however, it was concluded that pre-drilling cultivation was necessary because of soil compaction from animal trampling. Oat seed broadcast (after light cultivation) was successful, but not to the same extent as other methods, likely due to a compromise in soil-toseed contact. The establishment method of choice by farmers will depend on local factors revolving around soil and climatic conditions (including the amount of crop residues remaining), and there is unlikely to be a common method for all situations. However, nil or minimum tillage practices are likely to be advocated to minimise additional $\mathrm{N}$ being added to the system through mineralisation. On soils that are heavier or more prone to prolonged periods of water logging, successful catch crop establishment may rely on good management of the fallow soil after grazing to ensure suitable conditions for sowing and germination. For example, if conditions allow, immediately surface grubbing/ripping recently grazed land will allow soils to dry out more rapidly, enabling earlier access for soil preparation and/or sowing. In addition, the method used to establish the main winter crop (e.g. conventional cultivation versus direct-drilled fodder beet, kale etc.) may influence the level of compaction/pugging at grazing, and subsequently the establishment method and performance of the catch crop. This is an area for further investigation.

Integrating catch crops into farm production systems also needs to be carefully examined to ensure they fit successfully within existing grazing rotations. For example, sufficient time must be allowed between catch crop establishment and the sowing of the subsequent spring crop to maximise the feed benefits of catch crops. The timing around when spring feed is required (particularly on the milking platform where the land area is likely part of a grazing rotation), and whether there is sufficient irrigation for the following winter forage crop, may also be important considerations. As indicated above, the crucial months to achieve the desired environmental outcomes are during the winter and spring months until about mid-October. After this time the catch crop can be taken through to maturity for maximum yield potential (grain or forage), or terminated earlier (late-October) through grazing or green manuring, without compromising the environmental gains. These decisions are not likely to have important implications for $\mathrm{N}$ leaching. For arable systems, alternative cereal crops such as triticale, wheat and barley could be used as catch crops, which offers other uses for the crop such as whole-crop silage or grain. More work is required to understand the production potential of alternative crops that are sown in winter and taken through to different maturity stages, and the impact on $\mathrm{N}$ leaching in the subsequent drainage season.

Adding $\mathrm{N}$ fertiliser to catch crops may be necessary in some years to maximise productivity on some soil types. Work by Malcolm et al. (2017) showed that the crops did not respond consistently to $\mathrm{N}$ fertiliser applications in early-November, but this was attributed to a particularly dry winter-spring, and possibly a lack of soil moisture. Inevitably, yield responses to $\mathrm{N}$ are likely to be seen during years with higher winter/spring rainfall, and on lighter soils that leach more $\mathrm{N}$ and have lesser ability to supply $\mathrm{N}$ through mineralisation. Importantly, applying $\mathrm{N}$ fertiliser too early, such as when leaching losses are likely, may compromise the environmental benefits of catch crops.

\section{Conclusions}

The main conclusions drawn from this summary are:

- A winter-sown catch crop can reduce soil mineral N and consequently $\mathrm{N}$ leaching losses, primarily through $\mathrm{N}$ uptake (biomass and roots) and reduced drainage volume; research is required to quantify the potential role of enhanced microbial $\mathrm{N}$ immobilisation under catch crops

- The earlier the catch crop is established, the greater the potential to reduce $\mathrm{N}$ leaching (particularly on light free-draining soils) during periods of highest risk (winter to mid-October)

- Cereals (e.g. oats, ryecorn, triticale, wheat or barley) can be used as catch crops after winter grazing and are considered more effective than grass species (e.g. Italian ryegrass)

- Catch crop benefits vary depending on weather conditions, particularly during establishment; biophysical modelling tools can be used to better understand the outcomes of catch crops under 
various climatic and management factors, and predict $\mathrm{N}$ leaching reductions for various soils, regions and sowing timings

- Future work should consider the effects of catch crops over longer crop rotations to account for potential prolonged effects on leaching losses, i.e. over a second winter

- Catch crops can offer additional feed sources, with financial benefits. The end-use of the catch crops will depend on individual farm systems and the timing of feed requirements

- Direct-drilling or light pre-drilling cultivation should be targeted methods of establishment to minimise additional $\mathrm{N}$ input through mineralisation; however, more intensive cultivation may be necessary after heavy stock trampling and/or pugging. Further research should seek to identify suitable crop establishment methods that can overcome particularly challenging environments

- $\mathrm{N}$ fertiliser may be required in October/November to maximise crop productivity, e.g. after a wet winter on light soils

- There is an opportunity to identify the most important traits that offer the largest potential to reduce environmental impacts, which can then be targeted in future breeding initiatives.

\section{ACKNOWLEDGEMENTS}

This summary was completed as part of the Forages for Reduced Nitrate Leaching programme with principal funding from the New Zealand Ministry of Business, Innovation and Employmentand co-funding from research partners DairyNZ, AgResearch, Plant \& Food Research, Lincoln University, Foundation for Arable Research and Landcare Research.

\section{REFERENCES}

Carey, P.; Cameron, K.; Di, H.; Edwards, G. 2017. Comparison of nitrate leaching from oats and Italian ryegrass catch crops following simulated winter forage grazing: a field lysimeter study. New Zealand Journal of Agricultural Research 60: 298-318.

Carey, P.L.; Cameron, K.C.; Di, H.J.; Edwards, G.R. 2018. Does sowing an oats catch crop reduce nitrate leaching from urine deposition following simulated winter forage grazing? - A growth chamber experiment. Plant and Soil https://doi.org/10.1007/ s11104-018-3742-2.

Carey, P.L.; Cameron, K.C.; Di, H.J.; Edwards, G.R.; Chapman, D.F. 2016. Sowing a winter catch crop can reduce nitrate leaching losses from winter-applied urine under simulated forage grazing: a lysimeter study. Soil Use and Management 32: 329-337.

de Ruiter, J.M.; Hanson, R.; Hay, A.S.; Armstrong, K.W.; Harrison-Kirk, R.D. 2002. Whole-crop cereals for grazing and silage: balancing quality and quantity. Proceedings of the New Zealand Grassland Association 64: 181-189.

Edwards, G.R.; de Ruiter, J.M.; Dalley, D.E.; Pinxterhuis, J.B.; Cameron, K.C.; Bryant, R.H.; Malcolm, B.J.; Chapman, D.F. 2014. Dry matter intake and body condition score change of dairy cows grazing fodder beet, kale and kale-oat forage systems in winter. Proceedings of the New Zealand Grassland Association 76: 81-87.

Francis, G.S.; Haynes, R.J.; Williams, P.H. 1995. Effects of the timing of plowing-in temporary leguminous pastures and 2 winter cover crops on nitrogen mineralization, nitrate leaching and spring wheat growth. Journal of Agricultural Science 124: $1-9$.

Fraser, P.M.; Curtin, D.; Harrison-Kirk, T.; Meenken, E.D.; Beare, M.H.; Tabley, F.; Gillespie, R.N.; Francis, G.S. 2013. Winter nitrate leaching under different tillage and winter cover crop management practices. Soil Science Society of America Journal 77: 1391-1401.

Holzworth, D.P.; Huth, N.I.; deVoil, P.G.; Zurcher, E.J.; Herrmann, N.I.; McLean, G.; Chenu, K.; van Oosterom, E.J.; Snow, V.; Murphy, C.; Moore, A.D.; Brown, H.; Whish, J.P.M.; Verrall, S.; Fainges, J.; Bell, L.W.; Peake, A.S.; Poulton, P.L.; Hochman, Z.; Thorburn, P.J.; Gaydon, D.S.; Dalgliesh, N.P.; Rodriguez, D.; Cox, H.; Chapman, S.; Doherty, A.; Teixeira, E.; Sharp, J.; Cichota, R.; Vogeler, I.; Li, F.Y.; Wang, E.; Hammer, G.L.; Robertson, M.J.; Dimes, J.P.; Whitbread, A.M.; Hunt, J.; van Rees, H.; McClelland, T.; Carberry, P.S.; Hargreaves, J.N.G.; MacLeod, N.; McDonald, C.; Harsdorf, J.; Wedgwood, S.; Keating, B.A. 2014. APSIM Evolution towards a new generation of agricultural systems simulation. Environmental Modelling and Software 62: 327-350.

Kuzyakov, Y.; Domanski, G. 2000. Carbon input by plants into the soil. Review. Journal of Plant Nutrition and Soil Science 163: 421-431.

Malcolm, B.; Cameron, K.; Edwards, G.; Di, H.; de Ruiter, J.; Dalley, D. 2016a. Nitrate leaching losses from lysimeters simulating winter grazing of fodder beet by dairy cows. New Zealand Journal of Agricultural Research 59: 194-203.

Malcolm, B.; Teixeira, E.; Johnstone, P.; Maley, S.; de Ruiter, J.; Chakwizira, E. 2016b. Catch crops after winter grazing for production and environmental benefits. Agronomy New Zealand 46: 99-108.

Malcolm, B.; Teixeira, E.; Johnstone, P.; Maley, S.; de Ruiter, J.; Chakwizira, E. 2017. Establishment methods of oat catch crops after winter forage grazing. Agronomy New Zealand 47: 65-77.

Malcolm, B.J.; Moir, J.L.; Cameron, K.C.; Di, H.J.; 
Edwards, G.R. 2015. Influence of plant growth and root architecture of Italian ryegrass (Lolium multiflorum) and tall fescue (Festuca arundinacea) on $\mathrm{N}$ recovery during winter. Grass and Forage Science 70: 600-610.

McNally, S. 2016. Carbon inputs from roots of two contrasting pasture swards. PhD thesis, University of Waikato, Hamilton, New Zealand.

Monaghan, R.M.; Smith, L.C.; de Klein, C.A.M. 2013. The effectiveness of the nitrification inhibitor dicyandiamide (DCD) in reducing nitrate leaching and nitrous oxide emissions from a grazed winter forage crop in southern New Zealand. Agriculture Ecosystems \& Environment 175: 29-38.

Rees, R.; Bingham, I.; Baddeley, J.; Watson, C. 2005. The role of plants and land management in sequestering soil carbon in temperate arable and grassland ecosystems. Geoderma 128: 130-154.

Shepherd, M.; Stafford, A.; Smeaton, D. 2012. The use of a nitrification inhibitor $\left(\mathrm{DCn}^{\mathrm{TM}}\right)$ to reduce nitrate leaching under a winter-grazed forage crop in the Central Plateau. Proceedings of the New Zealand Grassland Association 74: 103-107.

Shepherd, M.; Carlson, B.; Lucci, G. 2017. The effect of time of winter urine deposition on mineral nitrogen leaching and implications for grazed forage crops. New Zealand Journal of Agricultural Research 60:
376-385.

Smith, L.C.; Orchiston, T.; Monaghan, R.M. 2012. The effectiveness of the nitrification inhibitor dicyandiamide (DCD) for mitigating nitrogen leaching losses from a winter grazed forage crop on a free draining soil in northern Southland. Proceedings of the New Zealand Grassland Association 74: 39-44.

Teixeira, E.; Johnstone, P.; Chakwizira, E.; de Ruiter, J.; Malcolm, B.; Shaw, N.; Zyskowski, R.; Khaembah, E.; Sharp, J.; Meenken, E.; Fraser, P.; Thomas, S.; Brown, H.; Curtin, D. 2016. Sources of variability in the effectiveness of winter cover crops for mitigating $\mathrm{N}$ leaching. Agriculture, Ecosystems and Environment 220: 226-235.

Yusoff, M.M.; Moot, D.J.; McKenzie, B.A.; Hill, G.D. 2012. Quantification of vegetative development of faba bean, oats, and Italian ryegrass. Crop \& Pasture Science 63: 1097-1105.

Zadoks, J.C.; Chang, T.T.; Konzak, C.F. 1974. A decimal code for the growth stages of cereals. Weed Research 14: 415-421.

Zyskowski, R.F.; Teixeira, E.I.; Malcolm, B.J.; Johnstone, P.R.; de Ruiter, J.M. 2016. Effectiveness of winter cover crops to reduce nitrogen leaching losses in cropping systems in Waikato, New Zealand. Agronomy New Zealand 46: 109-119. 